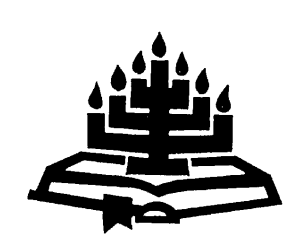

\title{
'n Homileties-empiriese ondersoek van prediking en gesindheidsverandering
}

\author{
F.P. Kruger \& C.J.H. Venter \\ Vakgroep Praktiese Teologie \\ Skool vir Kerkwetenskappe \\ Potchefstroomse Universiteit vir $\mathrm{CHO}$ \\ POTCHEFSTROOM \\ E-pos: fercel@lantic.net \\ kwscjhv@puknet.puk.ac.za
}

\begin{abstract}
A homiletical-empirical investigation of preaching and attitude change

The issues of preaching, and the change of attitude that preaching (should) bring about in the hearts and minds of hearers are dealt with in this article. In order to arrive at relevant and plausible conclusions, homiletical-empirical methodology was utilised. The aim of the article is to highlight the fact that both preachers and hearers have certain personal attitudes affecting the influence of preaching on their experience and realisation of faith. In this article a distinction is made between generic attitudes and attitudes towards specific issues. Generic attitudes consist of attitudes dependent on social circumstances and the influences of fellow-believers, attitudes with personal benefit as aim, and intrinsic-religious attitudes. Specific attitudes consist inter alia of the following aspects: the attitude of the hearers towards the Word, the congregation, worship, preaching as such, and expectations of the future. The article is concluded by selected perspectives for the praxis of preaching and attitude change.
\end{abstract}

\section{Opsomming \\ ' $n$ Homileties-empiriese ondersoek van prediking en gesindheids- verandering}

Die vraagstuk van prediking en die gesindheidsverandering wat in die hart en denke van die luisteraar behoort plaas te vind, word in hierdie artikel bespreek. Om relevante en aanvaarbare gevolgtrekkings te kon maak, is van homileties-empiriese ondersoekmetodes gebruik gemaak. Die doel van die artikel is om te benadruk dat sowel predikers as hoorders sekere persoonlike houdings het 
wat die uitwerking wat die prediking op hulle geloofservaring van die preekgegewens het, beïnvloed. In hierdie artikel word onderskei tussen generiese en spesifieke gesindhede of houdings. Generiese houdings of gesindhede bestaan uit gesindhede wat afhanklik is van sosiale faktore en kontak met medegelowiges, gesindhede wat persoonlike voordele soos troos of ondersteuning teweegbring en intrinsiek-religieuse gesindhede. Gesindhede teenoor spesifieke sake sluit onder andere die volgende in: die hoorders se houding of gesindheid teenoor die Woord, die gemeente, godsdiens, prediking en toekomsverwagting. Die artikel word afgesluit deur selektiewe perspektiewe te bied op die praxis van prediking en gesindheidsverandering.

\section{Inleiding}

Oor die teologiese grondslae van die prediking is reeds wyd besin in homiletiese literatuur. In tersaaklike vakliteratuur hieroor word verskillende teologiese perspektiewe gebied. Vos (1995:72-136) besin oor prediking vanuit 'n verbonds- en koninkryksperspektief waarin hy fokus op die koms van God na die mens in die wêreld en op die versteuring en herstel van die verhouding tussen God en mens. Vanuit 'n koninkryksperspektief rig hy ook die oog op Christologiese en Pneumatologiese dimensies in die prediking. Pieterse (1988:21-22) het reeds in 'n vroeëre publikasie die sentrale aanname gehad dat die prediking in die gemeente geskied as prediking van Jesus Christus. Hy is die Verlosser en kom self deur die Skrifteks heen aan die woord. In hierdie verband kan ook verwys word na die werk van Kruger en Venter (2002:573-592). Bogenoemde en ander teologiese grondlyne word deurgaans in hierdie artikel veronderstel - 'n artikel wat sterk op empiriese navorsing op metateoretiese vlak gaan fokus. Die motivering vir hierdie fokus is dat dit in die prediking gaan om die Woord van God wat die werklikheid binnedring. Daarom wil die artikel vanuit 'n eie empiriese hoek vra: hoe lyk hierdie werklikheid ten opsigte van gesindhede in die praktyk van die gemeentelike lewe? 'n Verdere motivering vir hierdie aanpak in die artikel is dat ons tyd gekenmerk word deur ingrypende veranderinge (Aday \& Andrew, 1996:32-33).

Aday en Andrew (1996:32-33) toon in hulle navorsing aan dat die twintigste eeu gekenmerk is deur groot veranderinge. Die een en twintigste eeu sal volgens bogenoemde outeurs ook geen uitsondering in dié verband wees nie. Die veranderinge hou ook gevolge in vir die gesindheid van hoorders. Verandering is vir sommige hoorders 'n uitdaging, maar vir talle ander hoorders ' $n$ faktor wat hulle bestaan bedreig. Hoorders reageer ook verskillend op verandering. Sommige hoorders maak asof die verandering nie bestaan nie, ander verwerp die gedagte 
van verandering, terwyl ander die verandering probeer ondermyn deur middel van allerlei subjektiewe interpretasies om sodoende die effek van verandering te minimaliseer. Aday en Andrew (1996:33) toon aan dat gebrekkige en swak kommunikasie dikwels die kernprobleem in veranderende tye en omstandighede is.

In die Praktiese Teologie toon navorsing 'n gerigtheid op die noodsaak van prediking wat gesindhede moet verander:

- Firet (1978:298) was een van die eerste navorsers uit die latere tyd wat wetenskaplike ondersoek in die Homiletiek oor gesindheidsverandering deur die prediking bepleit het. Hy noem die proses van begeleiding tot verandering agogie. Prediking dien as een van die modi in die toerusting van die gemeente tot verandering (Firet, 1978: 59; vgl. Nel, 1994:28). Binne hierdie begeleiding tot verandering moet twee momente onderskei word, naamlik 'n verstaansmoment en 'n veranderingsmoment (Firet, 1978:298).

- Cilliers (1996:1) het in sy werk kommer uitgespreek oor wettiese prediking wat nie mense se gesindhede verander nie, maar mense met die indruk laat dat hulle die potensiaal het om hulle probleme deur vroom insette op te los (Cilliers, 1996:7).

- Nel (1999:85) vestig in hulle ondersoek die aandag op die uiteenlopende aard van gesindhede van die Suid-Afrikaanse jeug. Die uiteenlopende aard van die gesindhede stel volgens die outeurs eise aan die praktiese bediening van die kerk.

- Vos (1999:126) toon aan dat prediking wat aan die adres van hoorders gerig word, hoorders op hulle lewensweg moet begelei.

- $\mathrm{Nel}$ (2000:112) toon in sy navorsing aan dat persoonlike prediking hoorders aanraak en in beweging bring. Hiermee bedoel die outeur dat die persoonlikheid van die prediker in die prediking ook 'n rol speel.

- Kruger (2002:198) toon aan dat die prediking saam met die ander gestaltes van gemeentelike bediening instrumenteel is in die verandering van gesindhede. Die prediking moet lidmate met hulle gesindhede voor die Woord van God te staan bring.

- Kruger en Venter (2002:589) benadruk die rol van prediking as motivering vir hoorders om hulle gesindhede wat nie in ooreenstemming met die Woord is nie, te verander. Die Woord is volgens bogenoemde outeurs die instellings- en vertrekpunt vir die verandering van gesindhede. 
Die seleksie vanuit relevante vakliteratuur oor die tema van prediking en gesindheidsverandering het getoon dat die saak rondom die gesindheid van die hoorders 'n aktuele ondersoekveld is. Vanuit die grenswetenskappe asook in die Praktiese Teologie is deur verskeie outeurs besin oor hoe gesindhede verander kan word. Die meerderheid outeurs is dit eens dat oorredende kommunikasie die wyse is waarop gesindhede verander kan word. Alhoewel die verskynsel gesindheidsverandering vanuit die seleksie van bronne aangetoon is, is die saak rondom gesindheidsverandering by hoorders nog nie by wyse van empiriese ondersoek getoets nie. Derhalwe het die artikel ten doel om by wyse van 'n gesindheidskaal 'n nadere ondersoek te doen na die gesindheid van hoorders. Verder word ook ondersoek of prediking daartoe kan bydra om verkeerde gesindhede te verander. Die primêre fokus van die artikel bly empiriese werk met die oog op die vasstelling van enkele tendense in die Suid-Afrikaanse konteks.

\section{Omskrywing van terminologie}

Binne die raamwerk van die onderwerp moet die begrippe gesindheid en gesindheidsverandering kortliks omskryf word:

\section{Gesindheid}

Vir die doel van die artikel word aangesluit by die WAT se definisie wat gesindheid onder andere omskryf as 'n "innerlike gevoel of houding" en "'n innerlike ingesteldheid" (WAT, 1972:180).

\section{Gesindheidsverandering}

Navorsing in die Praktiese Teologie het aangetoon dat veranderende tye die noodsaak van prediking wat gesindheidsverandering moet bewerkstellig, beklemtoon. Kim en Venter (1999:510) benadruk byvoorbeeld dat "[c]hanges are taking place at such a breath-taking pace that even experts in futuristic studies can not make reliable predictions". Hedendaagse hoorders leef met ander woorde in 'n situasie van verandering.

Burger (1994:83) spreek sy kommer uit oor die feit dat die prediking in 'n situasie van verandering nie gesindhede sodanig verander het soos wat verwag is nie. Hy toon aan dat die rol van kerke ook in die jare wat voorlê, selfs nog kleiner gaan wees. Daarom is dit noodsaaklik dat kerke en predikers opnuut sal besin oor die onvervangbare aard van die prediking in veranderende tye (Burger, 1994:90). Die prediking moet immers die hoorders mét hulle gesindhede in God se teenwoordigheid bring.

In prediking wat verandering moet bewerk, gaan dit dus nie om die vorming van hoorders na die hand van die prediker nie. Dit gaan eerder 
om hoorders te begelei en hul selfstandige menswees sodanig te erken dat die beeld van God al hoe meer in hom of haar tot gestalte kom (Smit, 1995:26).

Met gesindheidsverandering word daarom bedoel die leiding of begeleiding van hoorders deur middel van die prediking sodat die beeld van God al hoe meer in hulle vergestalt word.

\section{Metode van ondersoek}

\subsection{Metode}

Vir die navorsing wat hierdie artikel onderlê, is gebruik gemaak van die Likertskaal. Vir so 'n skaal stel die navorser 'n lys van items saam wat na sy mening gunstig of ongunstig verband hou met die gesindhede wat ondersoek word (Cilliers, 1983:103). Die items word as stellings geformuleer ten opsigte waarvan respondente kan aandui of hulle daarmee sterk verskil, matig verskil, neutraal staan, gedeeltelik saamstem of volkome saamstem (Dane, 1990:264). Numeriese waardes van 1-5 word aan die verskillende moontlike antwoorde by elke item toegeken. Die reaksie wat die meer gunstige gesindheid reflekteer, ontvang die hoogste numeriese waarde, en die gesindheid wat die ongunstigste gesindheid reflekteer, ontvang die laagste numeriese waarde. Die totale telling van elke respondent bestaan uit die som van die tellings ten opsigte van al die items tesame (Cilliers, 1983:103). Elke item word ontleed om vas te stel welke items die duidelikste onderskei tussen persone wat 'n hoë telling behaal en dié wat 'n lae telling behaal.

Die vraelyste is met kontakpersone in sewe gemeentes bespreek waarna die uitnodiging aan hoorders gerig is om te deel in die invul van die vraelys. Die navorsing is dus by wyse van beskikbaarheidseleksie gedoen, aangesien hoorders 'n keuse kon uitoefen in die invul van die vraelys. In die keuse van die sewe gemeentes is gepoog om 'n gebalanseerde verspreiding van plattelandse en stedelike gemeentes te betrek. By die uitdeel van die vraelyste is verder gelet op die verspreiding van die vraelyste aan hoorders tussen die ouderdom van 13 tot 70 jaar. Die motivering hiervoor is dat navorsing bewys het dat hoorders vanaf 13 tot 30 jaar makliker verander (Dingemans, 1991:95). Dingemans toon verder aan dat verandering na die ouderdom van 30 jaar moeisamer teweeggebring word. Die rede hiervoor is dat hoorders ouer as 30 jaar verkies om stil te staan by die interpretasiekaders van die puberteit. Dié verandering geld ook vir gesindhede van hoorders.

Die keuse van slegs sewe gemeentes binne vier Afrikaanse kerke mag moontlik neig na sydigheid in die navorsing. Tog is die doel van die 
studie nie om in die eerste plek 'n omvattende empiriese studie te doen nie, maar wel om vanuit die homileties-empiriese navorsing enkele neigings en tendense wat moontlik onder hoorders voorkom, nader te beskou.

\subsection{Respondente}

Die respondente het bestaan uit lidmate van die Gereformeerde Kerke in Suid-Afrika, die Nederduitse Gereformeerde Kerk, die Nederduitsch Hervormde Kerk van Afrika en die Afrikaanse Protestantse Kerk. Een honderd en twintig vraelyste is uitgedeel waarvan tagtig terugontvang is. Die vraelys is in sewe gemeentes deur lidmate tussen die ouderdom van 13 en 70 jaar voltooi. Die vraelys is deur manlike en vroulike lidmate voltooi met 'n balans tussen stedelike en plattelandse gemeentes.

\subsection{Meetinstrumente}

Cilliers (1983:101-103) asook Smit (1985:146-147) noem in hulle navorsing die vereistes waaraan meetinstrumente moet voldoen. Cilliers (1983:102) bespreek rangordeskale as 'n geldige meetinstrument. In teenstelling met oordeelskale waar van beoordelaars gebruik gemaak word, word rangordeskale opgestel deur middel van itemseleksie. Die numeriese waardes wat aan die items toegeken word met die statistiese verwerking hiervan, bewerkstellig 'n toets of meettelling. Die Likertskaal is 'n voorbeeld van die tegniek van skaalkonstruksie (Cilliers, 1983:103). Smit (1985:147) verwys in sy navorsing na die vereiste vir geldigheid wat gestel word. Dié outeur toon aan dat die data wat ingesamel word, informasie moet verskaf oor die veld van ondersoek.

In die opstel van die vraelys is items (stellings) geformuleer wat te make het met prediking, die prediker, hoorders en gesindheidsverandering. Die vraelys val uiteen in twee soorte (tipes) gesindhede, naamlik soorte gesindhede en gesindhede teenoor spesifieke sake. Die soorte gesindhede word onderverdeel in gesindhede wat afhanklik is van sosiale omstandighede in lidmate se kontak met mekaar; gesindhede wat persoonlike voordeel in die oog het en intrinsiek-godsdienstige gesindhede.

Die gesindhede ten opsigte van spesifieke aspekte word onderverdeel in gesindhede teenoor die Woord, gesindhede teenoor die gemeente en gesindhede teenoor die prediking.

Die items voldoen dus aan die vereistes hierbo gestel, omdat die items spesifiek gerig is op die saak wat ondersoek word, naamlik prediking en die gesindheidsverandering by hoorders. 


\subsection{Die Likertskaal}

\section{Biografiese gegewens}

Tagtig $(65,8 \%)$ uit 'n moontlike een honderd en twintig respondente het gereageer op die uitnodiging om die vraelys in te vul. Die response is verteenwoordigend van plattelandse sowel as van stedelike gemeentes. Uit die platteland het 39 respondente (48,75\%) gereageer, terwyl 41 $(51,25 \%)$ respondente uit stedelike gemeentes gereageer het.

Een en vyftig (63,75\%) manlike respondente en 29 (36,25\%) vroulike respondente het gereageer. Die vraelys is versprei onder lidmate tussen die ouderdomme van 13 en 70 . Hieruit blyk dit dat die response op die verskillende gesindhede verteenwoordigend is van lidmate tussen die ouderdomme van 13 en 70 jaar.

\section{Soorte gesindhede}

In hierdie onderafdeling word die drie soorte gesindhede kortliks omlyn en word die response op stellings ontleed.

\subsection{Gesindhede wat afhanklik is van kerklik-sosiaal omstandig- hede}

Hierdie tipe gesindhede weerspieël die mate waarin kerklike betrokkenheid afhanklik is van kontak met ander lidmate.

1. "Die gemeente is vir my koud omdat ek nie hegte bande met die gemeente het nie". Op hierdie stelling het respondente soos volg gereageer:

\begin{tabular}{|c|c|c|c|c|}
\hline Stelling & Frekwensie & Persentasie & $\begin{array}{l}\text { Kumulatiewe } \\
\text { frekwensie }\end{array}$ & $\begin{array}{l}\text { Kumulatiewe } \\
\text { persentasie }\end{array}$ \\
\hline 1 & 43 & 53,75 & 46 & 53,75 \\
\hline 2 & 16 & 20,00 & 59 & 73,75 \\
\hline 3 & 6 & 7,50 & 65 & 81,25 \\
\hline 4 & 9 & 11,25 & 74 & 92,50 \\
\hline 5 & 6 & 7,50 & 80 & 100,00 \\
\hline
\end{tabular}

Die respons beklemtoon die feit dat die meerderheid van die respondente die kerk waarvan hulle lidmaat is, nie as koud ervaar nie. Slegs $7,5 \%$ van die respondente ervaar hul gemeentes as koud vanweë 
gebrekkige meelewing met ander lidmate, terwyl 11,25\% gedeeltelik met die stelling saamstem. Dit is opmerklik dat $7,5 \%$ van die respondente neutraal staan teenoor die stelling. Bogenoemde respons onderstreep die belangrike plek en funksie van 'n gesonde verhouding met ander lidmate.

2. "Die predikant se gesindheid (positief of negatief) beïnvloed my meelewing met die gemeente (positief of negatief)". Op stelling 2 het die respondente soos volg gereageer:

\begin{tabular}{|c|r|r|r|r|}
\hline Stelling & Frekwensie & Persentasie & \multicolumn{1}{|l|}{$\begin{array}{l}\text { Kumulatiewe } \\
\text { frekwensie }\end{array}$} & $\begin{array}{l}\text { Kumulatiewe } \\
\text { persentasie }\end{array}$ \\
\hline 1 & 14 & 17,50 & 14 & 17,50 \\
\hline 2 & 8 & 10,00 & 22 & 27,50 \\
\hline 3 & 7 & 8,75 & 29 & 36,25 \\
\hline 4 & 24 & 30,00 & 53 & 66,25 \\
\hline 5 & 27 & 33,75 & 80 & 100,00 \\
\hline
\end{tabular}

Die meerderheid van die respondente $(63,75 \%)$ het aangedui dat hulle óf gedeeltelik óf volkome met die stelling saamstem dat die gesindheid van die predikant hulle positief of negatief beïnvloed. $27,5 \%$ van die respondente het aangedui dat hulle matig of sterk verskil van die stelling, terwyl $8,75 \%$ neutraal teenoor die stelling gestaan het. Dit is nie heeltemal duidelik waarom respondente neutraal staan teenoor genoemde stelling nie.

3. "Ek het behoefte om met medegelowiges oor die predikant se preke te gesels". Op stellng 3 is soos volg gereageer:

\begin{tabular}{|c|r|r|r|r|}
\hline Stelling & Frekwensie & Persentasie & $\begin{array}{l}\text { Kumulatiewe } \\
\text { frekwensie }\end{array}$ & $\begin{array}{l}\text { Kumulatiewe } \\
\text { persentasie }\end{array}$ \\
\hline 1 & 2 & 2,53 & 2 & 2,53 \\
\hline 2 & 2 & 2,53 & 4 & 5,06 \\
\hline 3 & 23 & 29,11 & 27 & 34,18 \\
\hline 4 & 22 & 27,85 & 49 & 63,03 \\
\hline 5 & 30 & 37,97 & 79 & 100,00 \\
\hline
\end{tabular}


Die meerderheid respondente $(65,82 \%)$ stem gedeeltelik of volkome saam dat hulle behoefte het om met gelowiges oor die predikant se preke te gesels. Slegs 5,06\% van die respondente verskil sterk of matig van die stelling, terwyl $29,11 \%$ van die respondente neutraal teenoor dié stelling staan. Die respons benadruk die feit dat hoorders graag met ander hoorders oor preke wil gesels, terwyl 'n beduidende hoeveelheid heeltemal neutraal teenoor die saak staan.

Die response op stelling 1-3 benadruk die feit opnuut dat hoorders 'n invloed op mekaar uitoefen ten opsigte van erediensbywoning, die aanhoor van preke, asook in hulle interaksie met mekaar. Die response beklemtoon die feit dat die hoorders en prediker se gesindheid in 'n wisselwerking ten opsigte van mekaar staan.

\subsection{Geleenthede wat voortvloei uit die persoonlike voordele wat dit teweegbring}

Gesindhede wat persoonlike voordeel nastreef, het te make met die mate waarin die betekenis van iemand se godsdiens gesoek word in persoonlike troos, steun en die veiligheid wat dit bied. Respondente het soos volg gereageer op stelling 4: "Indien ek preke nie verstaan nie en dit nie vir my verduidelik hoe ek moet lewe nie, is dit nie die moeite werd om eredienste by te woon nie":

\begin{tabular}{|c|r|r|r|r|}
\hline Stelling & Frekwensie & Persentasie & $\begin{array}{l}\text { Kumulatiewe } \\
\text { frekwensie }\end{array}$ & $\begin{array}{l}\text { Kumulatiewe } \\
\text { persentasie }\end{array}$ \\
\hline 1 & 45 & 56,25 & 45 & 56,25 \\
\hline 2 & 14 & 17,50 & 59 & 73,75 \\
\hline 3 & 4 & 5,00 & 63 & 78,75 \\
\hline 4 & 11 & 13,75 & 74 & 92,50 \\
\hline 5 & 6 & 7,50 & 80 & 100,00 \\
\hline
\end{tabular}

Die meerderheid van die respondente $(73,75 \%)$ verskil sterk of matig van die stelling. Uit die respons blyk die positiewe gesindheid by respondente dat eredienste noodsaaklik is - selfs ten spyte van die verskynsel dat preke soms "onverstaanbaar" mag wees. Die response wys ook 'n bron van kommer uit: $21,25 \%$ van die respondente het naamlik te kenne gegee dat hulle gedeeltelik of volkome saamstem dat onverstaanbare preke die sinvolheid van eredienste beïnvloed. Alhoewel die meerderheid van die respondente positief reageer op eredienste, blyk daar tog 'n bron vir kommer te wees, omdat sommige hoorders onverstaanbare 
prediking as 'n rede aantoon waarom die sinvolheid van erediensbywoning in gedrang kom.

Die respondente het soos volg gereageer op stelling 5: "Die belangrikste doel van preke is om praktiese hulp hieruit te verkry":

\begin{tabular}{|c|r|r|r|r|}
\hline Stelling & Frekwensie & Persentasie & $\begin{array}{l}\text { Kumulatiewe } \\
\text { frekwensie }\end{array}$ & $\begin{array}{l}\text { Kumulatiewe } \\
\text { persentasie }\end{array}$ \\
\hline 1 & 8 & 10,00 & 8 & 10,00 \\
\hline 2 & 7 & 8,75 & 15 & 18,75 \\
\hline 3 & 9 & 11,25 & 24 & 30,00 \\
\hline 4 & 24 & 30,00 & 48 & 60,00 \\
\hline 5 & 32 & 40,00 & 80 & 100,00 \\
\hline
\end{tabular}

Die meerderheid van die respondente (70\%) stem saam dat die belangrikste doel van preke is om praktiese hulp hieruit te verkry. Dié respons korreleer met stelling 4 waarin respondente aangetoon het dat, indien preke nie verstaanbaar is of verduidelik hoe hoorders moet lewe nie, dit nie die moeite werd is om eredienste by te woon nie. Hoorders het 'n sterk behoefte aan aktuele prediking. 'n Beduidende aantal respondente $(11,25 \%)$ het 'n neutrale gesindheid teenoor genoemde stelling 5. Bogenoemde twee response toon aan dat die betekenis van die prediking vir die meerderheid van die hoorders opgesluit lê in die troos en leiding wat hieruit geput word. Die rol van prediking in gemeentelike toerusting mag daarom nie geringgeskat word nie.

\subsection{Intrinsiek-godsdienstige gesindhede}

Intrinsiek-godsdienstige gesindhede het te make met die gerigtheid op die verhouding met God en die strewe om dié verhouding met die alledaagse lewe te verbind. Stelling 6 en 7 het te make met intrinsiekgodsdienstige gesindhede. Respondente het soos volg op stelling 6 gereageer ("Geloof in God stel my elke dag in staat om met oortuiging te lewe en op te tree"):

\begin{tabular}{|c|r|r|r|r|}
\hline Stelling & Frekwensie & Persentasie & $\begin{array}{l}\text { Kumulatiewe } \\
\text { frekwensie }\end{array}$ & $\begin{array}{l}\text { Kumulatiewe } \\
\text { persentasie }\end{array}$ \\
\hline 4 & 2 & 2,50 & 2 & 2,50 \\
\hline 5 & 78 & 97,50 & 80 & 100,00 \\
\hline
\end{tabular}


Al die respondente het gedeeltelik of volkome saamgestem met die stelling: "Geloof in God stel my elke dag in staat om met oortuiging te lewe en op te tree". Hieruit blyk dat hoorders die gesindheid openbaar om daagliks vanuit die geloof te lewe en op te tree. Dit is ' $n$ gesindheid wat reeds in die kinderjare (ongeveer op 13 jaar) begin ontwikkel. Dié fase staan bekend as die operasionele fase in kognitiewe ontwikkeling (Prins, 2000:86). Vanaf die ouderdom van 13 jaar leer mense om abstrak te dink en te redeneer.

Respondente het soos volg gereageer op stelling 7: "Indien ek besluite neem, dink ek terug aan preke wat verband hou met die besluite wat ek moet neem":

\begin{tabular}{|c|r|r|r|r|}
\hline Stelling & Frekwensie & Persentasie & $\begin{array}{l}\text { Kumulatiewe } \\
\text { frekwensie }\end{array}$ & $\begin{array}{l}\text { Kumulatiewe } \\
\text { persentasie }\end{array}$ \\
\hline 1 & 2 & 2,53 & 2 & 2,53 \\
\hline 2 & 2 & 2,53 & 4 & 5,06 \\
\hline 3 & 13 & 16,46 & 17 & 21,52 \\
\hline 4 & 35 & 44,35 & 52 & 65,82 \\
\hline 5 & 27 & 34,10 & 79 & 100,00 \\
\hline
\end{tabular}

Die meerderheid van die respondente $(77,48 \%)$ het te kenne gegee dat hulle óf gedeeltelik óf volkome daarmee saamstem dat preke as beginselraamwerk dien in belangrike besluite wat geneem moet word. Slegs $34,18 \%$ het volkome met die stelling saamgestem, terwyl 44,3\% van die respondente gedeeltelik saamgestem het. ' $n$ Redelike hoeveelheid van die respondente $(16,46 \%)$ het 'n neutrale gesindheid in hierdie opsig geopenbaar. Slegs $7,59 \%$ van die respondente het matig of sterk van die stelling verskil. Op grond hiervan word die afleiding gemaak dat daar by hoorders ' $n$ sterk neiging bestaan om vanuit die beginselraamwerk wat preke daarstel, betrokke te wees by belangrike besluite wat geneem moet word. In dié opsig toon die respondente 'n positiewe gesindheid ten opsigte van prediking.

\section{Gesindhede ten opsigte van spesifieke sake}

In hierdie onderafdeling word gesindhede teenoor spesifieke sake ondersoek, waarna die response ontleed word. 


\subsection{Gesindhede teenoor die Woord}

Stelling 8 en 9 is gemik op die gesindheid van hoorders teenoor die Woord.

Respondente het soos volg gereageer op stelling 8: "Ek rig my lewe in volgens God se Woord":

\begin{tabular}{|c|r|r|r|r|}
\hline Stelling & Frekwensie & Persentasie & $\begin{array}{l}\text { Kumulatiewe } \\
\text { frekwensie }\end{array}$ & $\begin{array}{l}\text { Kumulatiewe } \\
\text { persentasie }\end{array}$ \\
\hline 3 & 2 & 2,50 & 2 & 2,50 \\
\hline 4 & 19 & 23,75 & 21 & 26,25 \\
\hline 5 & 59 & 73,75 & 80 & 100,00 \\
\hline
\end{tabular}

Die meerderheid van die respondente $(97,5 \%)$ dui aan dat hulle hul lewens volgens God se Woord inrig. In dié opsig is 2,5\% van die respondente neutraal teenoor dié stelling.

Respondente het soos volg gereageer op stelling 9: "Ek is bereid om my gesindheid en optrede te verander indien God se Woord dit van my eis":

\begin{tabular}{|c|r|r|r|r|}
\hline Stelling & Frekwensie & Persentasie & $\begin{array}{l}\text { Kumulatiewe } \\
\text { frekwensie }\end{array}$ & $\begin{array}{l}\text { Kumulatiewe } \\
\text { persentasie }\end{array}$ \\
\hline 1 & 1 & 1,25 & 1 & 1,25 \\
\hline 2 & 1 & 1,25 & 2 & 2,50 \\
\hline 4 & 6 & 7,50 & 8 & 10,00 \\
\hline 5 & 72 & 90,00 & 80 & 100,00 \\
\hline
\end{tabular}

Die meerderheid van die respondente $(97,5 \%)$ het aangedui dat hulle gedeeltelik of volkome met die stelling saamstem. Hieruit word 'n positiewe gesindheid afgelei teenoor prediking wat meewerk om verkeerde gesindhede te verander. Hoorders openbaar ' $n$ bereidheid om te verander indien God se Woord dit eis. Dit is daarom noodsaaklik dat prediking Woordverkondiging sal wees wat erns maak met die verklaring en toepassing van die Woord. Slegs $3,75 \%$ van die hoorders het aangedui dat hulle matig of sterk verskil van die stelling. Alhoewel hierdie artikel primer fokus op empiriese aspekte, moet aangetoon word dat bogenoemde hoordersrespons 'n belangrike tendens binne die SuidAfrikaanse konteks vorm. Heyns (1982:1-4) het vroeër al vanuit teologies-etiese hoek gewys op die feit dat die veranderinge binne Suid- 
Afrikaanse konteks die mens voor enorme vraagstukke van sowel teoretiese as praktiese aard geplaas het. Dié veranderinge het selfondersoekende vrae by die mens na vore gebring. Die gelowige word daarom ook verplig om homself ten opsigte van die veranderinge te verantwoord. In bogenoemde respons het die meerderheid hoorders aangetoon dat hulle bereid is om hulle gesindhede te verander indien die Woord dit van hulle eis. Die positiewe gesindheid van hoorders hou ook implikasies in vir die gesindheidsdimensie binne die Suid-Afrikaanse konteks ten opsigte van sake soos volkereverhoudings, die ingesteldheid van gelowiges teenoor vigs, misdaad asook armoede.

\subsection{Gesindhede teenoor die gemeente}

Stelling 10 en 11 is daarop gemik om die gesindhede van hoorders teenoor die gemeente vas te stel. Die respondente het soos volg gereageer op stelling 10: "Ek voel tuis in ons gemeente":

\begin{tabular}{|c|r|r|r|r|}
\hline Stelling & Frekwensie & Persentasie & $\begin{array}{l}\text { Kumulatiewe } \\
\text { frekwensie }\end{array}$ & $\begin{array}{l}\text { Kumulatiewe } \\
\text { persentasie }\end{array}$ \\
\hline 1 & 1 & 1,25 & 1 & 1,25 \\
\hline 2 & 1 & 1,25 & 2 & 2,50 \\
\hline 3 & 4 & 5,00 & 6 & 7,50 \\
\hline 4 & 15 & 18,75 & 21 & 26,25 \\
\hline 5 & 59 & 73,75 & 80 & 100,00 \\
\hline
\end{tabular}

Die respondente se reaksie op stelling 10: "Ek voel tuis in ons gemeente", korreleer met stelling 1 waar die meerderheid van die respondente matig of sterk verskil het van die stelling dat die gemeente vir hulle koud is, omdat hulle nie hegte bande met die gemeente het nie. Die meerderheid respondente $(92,5 \%)$ openbaar 'n positiewe gesindheid teenoor die stelling dat hulle tuis voel in die gemeente.

Respondente het soos volg gereageer op stelling 11: "Die gesindheid van ander lidmate beïnvloed my (positief en/of negatief)" (kyk op die volgende bladsy):

Die meerderheid van die respondente $(52,5 \%)$ stem gedeeltelik of volkome saam dat die gesindheid van ander lidmate hulle beïnvloed. Uit die gesindheidskaal blyk dit dat 33,75\% van die respondente meen dat die gesindheid van ander lidmate hulle nie beïnvloed nie. 'n Groot persentasie $(82,5 \%)$ van die respondente wat meen dat die gesindheid 
van ander lidmate hulle nie beïnvloed nie, is bo die ouderdom van 50 jaar. Hieruit word afgelei dat die meerderheid jonger mense (13-50 jaar) meer ontvanklik is vir die gesindhede van ander hoorders (lidmate). Richards (1988:19) het aangetoon dat die waarde van 'n geloofslewe aan jonger mense oorgedra word deur betrokkenheid in, en deelname aan die lewe van die geloofsgemeenskap. Identifisering met medegelowiges is vir jonger mense van groot belang.

\begin{tabular}{|c|r|r|r|r|}
\hline Stelling & Frekwensie & Persentasie & $\begin{array}{l}\text { Kumulatiewe } \\
\text { frekwensie }\end{array}$ & $\begin{array}{l}\text { Kumulatiewe } \\
\text { persentasie }\end{array}$ \\
\hline 1 & 17 & 21,25 & 17 & 21,25 \\
\hline 2 & 10 & 12,50 & 27 & 33,75 \\
\hline 3 & 11 & 13,75 & 38 & 47,50 \\
\hline 4 & 32 & 40,00 & 70 & 87,50 \\
\hline 5 & 10 & 12,50 & 80 & 100,00 \\
\hline
\end{tabular}

\subsection{Gesindhede teenoor die erediens en prediking}

Die gesindhede teenoor die erediens en prediking word in stellings 12-19 aan die orde gestel. Respondente het soos volg gereageer op stelling 12: "Eredienste is vir my insiggewend, omdat ek baie hieruit leer":

\begin{tabular}{|c|r|r|r|r|}
\hline Stelling & Frekwensie & Persentasie & $\begin{array}{l}\text { Kumulatiewe } \\
\text { frekwensie }\end{array}$ & $\begin{array}{l}\text { Kumulatiewe } \\
\text { persentasie }\end{array}$ \\
\hline 3 & 2 & 2,50 & 2 & 2,50 \\
\hline 4 & 18 & 22,50 & 20 & 25,00 \\
\hline 5 & 60 & 75,00 & 80 & 100,00 \\
\hline
\end{tabular}

Van groot belang is die feit dat $97,5 \%$ van die respondente 'n positiewe gesindheid teenoor eredienste openbaar. In dié opsig is dit ook van belang om daarop te let dat 2,5\% van die respondente 'n neutrale gesindheid ten opsigte van bogenoemde stelling openbaar. Uit die oorweldigend positiewe respons word afgelei dat hoorders baat vind by eredienste. Hoorders verkeer immers onder die erediens in ontmoeting met God.

Die respondente het soos volg gereageer op stelling 13: "Omdat preke langdradig is, sukkel ek om te konsentreer": 
F.P. Kruger \& C.J.H. Venter

\begin{tabular}{|c|r|r|r|r|}
\hline Stelling & Frekwensie & Persentasie & $\begin{array}{l}\text { Kumulatiewe } \\
\text { frekwensie }\end{array}$ & $\begin{array}{l}\text { Kumulatiewe } \\
\text { persentasie }\end{array}$ \\
\hline 1 & 25 & 31,25 & 25 & 31,25 \\
\hline 2 & 12 & 15,00 & 37 & 46,25 \\
\hline 3 & 7 & 8,75 & 44 & 55,00 \\
\hline 4 & 30 & 37,50 & 74 & 92,50 \\
\hline 5 & 6 & 7,50 & 80 & 100,00 \\
\hline
\end{tabular}

Ten opsigte van konsentrasieprobleme as gevolg van langdradige preke was daar uiteenlopende reaksies. Altesaam 46,25\% van die respondente het aangetoon dat hulle matig of sterk verskil van die stelling, terwyl $45 \%$ van die respondente aangetoon het dat hulle gedeeltelik of volkome met die stelling saamstem.

Dit moet gemeld word dat 31,25\% sterk verskil van die stelling hierbo gemaak, terwyl net 7,5\% volkome met die stelling saamstem. Uit die response blyk dit dat predikers opnuut moet let op die wyse van preekoordrag om hoorders effektief in staat te stel om God se stem te hoor. Predikers mag nie die preekstoel so vol staan dat hoorders God nie kan hoor praat nie. Uit die response blyk dit dat $8,75 \%$ van die respondente neutraal teenoor die stelling staan. Aangesien dit 'n gesindheidskaal is waarmee gewerk word, is dit nie duidelik waarom die respondente 'n neutrale gesindheid in dié verband het nie.

Uit die respons op stelling 12 het dit geblyk dat hoorders 'n positiewe gesindheid ten opsigte van eredienste ervaar. Op grond van die respons op stelling 13 blyk dit dat respondente verskil in hul reaksies oor die geslaagdheid van hul luister-aksie wanneer preke langdradig is.

Respondente het soos volg gereageer op stelling 14: "'n Goeie preek is 'n preek wat verduidelik wat die teks sê en hoe ek dit in my lewe moet toepas":

\begin{tabular}{|c|r|r|r|r|}
\hline Stelling & Frekwensie & Persentasie & $\begin{array}{l}\text { Kumulatiewe } \\
\text { frekwensie }\end{array}$ & $\begin{array}{l}\text { Kumulatiewe } \\
\text { persentasie }\end{array}$ \\
\hline 2 & 3 & 3,75 & 3 & 3,75 \\
\hline 3 & 2 & 2,50 & 5 & 6,25 \\
\hline 4 & 16 & 20,00 & 21 & 26,25 \\
\hline 5 & 59 & 73,25 & 80 & 100,00 \\
\hline
\end{tabular}


Die meerderheid van die respondente $(93,25 \%)$ het aangetoon dat 'n goeie preek aantoon wat die teks sê en verduidelik hoe die preekstof in die praktyk van die lewe toegepas moet word. Die prediker moet in sy preekvoorbereiding getrou aan die teks wees en die behoeftes van die hoorders in ag neem. Alhoewel respondente ten opsigte van stelling 13 aangedui het dat hulle sukkel om te konsentreer wanneer preke langdradig is, openbaar hulle wel 'n gunstige gesindheid teenoor prediking wat die teksinhoud so verduidelik dat hulle dit in hulle lewens kan toepas.

Respondente het soos volg gereageer op stelling 15: "Preke wat my verkeerde gewoontes betrek, laat my ongemaklik voel":

\begin{tabular}{|c|r|r|r|r|}
\hline Stelling & Frekwensie & Persentasie & $\begin{array}{l}\text { Kumulatiewe } \\
\text { frekwensie }\end{array}$ & $\begin{array}{l}\text { Kumulatiewe } \\
\text { persentasie }\end{array}$ \\
\hline 1 & 6 & 7,50 & 6 & 7,50 \\
\hline 2 & 6 & 7,50 & 12 & 15,00 \\
\hline 3 & 5 & 6,25 & 71 & 21,25 \\
\hline 4 & 16 & 20,00 & 33 & 41,25 \\
\hline 5 & 47 & 58,78 & 80 & 100,00 \\
\hline
\end{tabular}

Die meerderheid respondente $(78,75 \%)$ het laat blyk dat preke wat hulle verkeerde gewoontes betrek, hulle ongemaklik laat voel. 'n Redelike hoeveelheid (15\%) het laat blyk dat hulle matig of sterk verskil van die stelling, terwyl 6,25\% neutraal teenoor die stelling staan. Dit blyk dat prediking ' $n$ groot rol kan speel in die verandering van verkeerde gesindhede.

Respondente het soos volg gereageer op stelling 16: "Preke wat my skuldig laat voel, gee daartoe aanleiding dat ek graag met my predikant wil gesels met die oog op verdere leiding":

\begin{tabular}{|c|r|r|r|r|}
\hline Stelling & Frekwensie & Persentasie & $\begin{array}{l}\text { Kumulatiewe } \\
\text { frekwensie }\end{array}$ & $\begin{array}{l}\text { Kumulatiewe } \\
\text { persentasie }\end{array}$ \\
\hline 2 & 5 & 6,25 & 5 & 6,25 \\
\hline 3 & 23 & 28,75 & 28 & 35,00 \\
\hline 4 & 26 & 32,50 & 54 & 67,50 \\
\hline 5 & 26 & 32,50 & 80 & 100,00 \\
\hline
\end{tabular}


'n Groot aantal respondente (65\%) het aangedui dat preke wat hulle skuldig laat voel, by hulle 'n behoefte skep om met hul predikant hieroor te gesels. Dieselfde persentasie respondente $(32,5 \%)$ het aangetoon dat hulle gedeeltelik of volkome met die stelling saamstem. Slegs $6,25 \%$ van die respondente het te kenne gegee dat hulle matig van die stelling verskil, terwyl $28,75 \%$ 'n neutrale gesindheid openbaar in dié verband. Prediking wat hoorders in hulle bestaan van hier en nou opskerp, skep verdere toerustingsgleenthede by wyse van persoonlike kontak met lidmate en deur middel van die ander gestaltes (modi) van gemeentelike bediening. Prediking staan immers nooit in isolasie in gemeentelike bediening nie.

Respondente het soos volg gereageer op stelling 17: "Die predikant se preke bring my nader aan God":

\begin{tabular}{|c|r|r|r|r|}
\hline Stelling & Frekwensie & Persentasie & $\begin{array}{l}\text { Kumulatiewe } \\
\text { frekwensie }\end{array}$ & $\begin{array}{l}\text { Kumulatiewe } \\
\text { persentasie }\end{array}$ \\
\hline 1 & 1 & 1,25 & 1 & 1,25 \\
\hline 2 & 1 & 1,25 & 2 & 2,50 \\
\hline 3 & 3 & 3,75 & 5 & 6,25 \\
\hline 4 & 20 & 25,00 & 25 & 31,25 \\
\hline 5 & 55 & 68,75 & 80 & 100,00 \\
\hline
\end{tabular}

Die meerderheid respondente $(93,75 \%)$ het aangetoon dat die predikant se preke hulle nader aan God bring.

Die respondente het soos volg gereageer op stelling 18: "Ek het vrymoedigheid om met my predikant oor sy preke te gesels":

\begin{tabular}{|c|r|r|r|r|}
\hline Stelling & Frekwensie & Persentasie & $\begin{array}{l}\text { Kumulatiewe } \\
\text { frekwensie }\end{array}$ & $\begin{array}{l}\text { Kumulatiewe } \\
\text { persentasie }\end{array}$ \\
\hline 1 & 2 & 2,50 & 2 & 2,50 \\
\hline 2 & 2 & 2,50 & 4 & 5,00 \\
\hline 3 & 12 & 15,00 & 16 & 20,00 \\
\hline 4 & 12 & 15,00 & 28 & 35,00 \\
\hline 5 & 52 & 65,00 & 80 & 100,00 \\
\hline
\end{tabular}


Onder stelling 17 het die meerderheid van die respondente aangetoon dat die predikant se preke hulle nader aan God bring. Onder stelling 18 het $65 \%$ van die respondente aangetoon dat hulle volkome saamstem dat hulle die vrymoedigheid het om met hulle predikant oor sy preke te gesels. 'n Verdere 15\% van die respondente het aangetoon dat hulle gedeeltelik saamstem daarmee dat hulle die vrymoedigheid het om met hulle predikant oor sy preke te gesels. Slegs $5 \%$ van die respondente het aangetoon dat hulle nie die vrymoedigheid het om met hulle predikant oor sy preke te gesels nie. Die preekgesprek voor en na die prediking help predikers om nie hul preekvoorbereiding in eensaamheid te ervaar nie, en neem sodoende die gemeente mee op die weg van preekvoorbereiding en preeklewering. Hoorders kry langs die weg van gesprek met die predikant geleentheid om 'n dieptegesprek oor sy preke te voer.

\section{Afleidings oor stellings 12-18}

- Respondente (hoorders) openbaar 'n positiewe gesindheid ten opsigte van eredienste omdat die prediking vir hulle insiggewend is.

- Hoorders sukkel dikwels, vanweë langdradige prediking, om op die prediking te konsentreer. Predikers moet bedag wees op die gevaar dat hulle dikwels te veel wil sê en sodoende in die slaggat trap om langdradig oor te kom.

- Hoorders openbaar 'n gunstige gesindheid ten opsigte van preke wat verduidelik wat die teks sê sodat die hoorders dit in die praktyk kan toepas.

- Die hoorders ervaar ongemak indien preke hulle verkeerde gewoontes betrek.

- Preke wat hoorders skuldig laat voel, skep 'n behoefte by lidmate om met hulle predikant daaroor te gesels. Deurleefde en egte prediking stimuleer die wisselwerking tussen die verskillende modi in gemeentelike bediening.

- Hoorders openbaar 'n gunstige gesindheid teenoor prediking, omdat preke hulle nader aan God bring.

\subsection{Gesindhede oor die toekoms}

Die gesindheid oor die toekoms is nie slegs 'n addendum by die geloofslewe nie, maar 'n essensiële deel daarvan (Prins, 2000:92). Stelling 19-22 handel oor hoorders se gesindhede oor die toekoms.

Respondente het soos volg gereageer op stelling 19: "Ek is opgewonde oor die toekoms": 
F.P. Kruger \& C.J.H. Venter

\begin{tabular}{|c|r|r|r|r|}
\hline Stelling & Frekwensie & Persentasie & $\begin{array}{l}\text { Kumulatiewe } \\
\text { frekwensie }\end{array}$ & $\begin{array}{l}\text { Kumulatiewe } \\
\text { persentasie }\end{array}$ \\
\hline 1 & 7 & 8,75 & 7 & 8,75 \\
\hline 2 & 4 & 5,00 & 11 & 13,75 \\
\hline 3 & 18 & 22,50 & 29 & 36,25 \\
\hline 4 & 20 & 25,00 & 49 & 61,25 \\
\hline 5 & 31 & 38,75 & 80 & \\
\hline
\end{tabular}

Respondente se reaksie op dié stelling was uiteenlopend. Slegs 38,75\% van die respondente stem volkome saam dat hulle opgewonde oor die toekoms is, terwyl $25 \%$ gedeeltelik saamstem met die stelling. Al die respondente tussen 13-30 het aangetoon dat hulle opgewonde oor die toekoms is. Die meerderheid van die ouer respondente tussen 31-75 het aangetoon dat hulle matig of sterk verskil van die stelling. Die oorgangstye wat hoorders op vele terreine beleef, word op verskillende maniere ervaar en verwerk. $22,5 \%$ van die respondente openbaar 'n neutrale gesindheid oor die toekoms.

Respondente het soos volg gereageer op stelling 20: "Die verandering in ons land maak my negatief":

\begin{tabular}{|c|r|r|r|r|}
\hline Stelling & Frekwensie & Persentasie & $\begin{array}{l}\text { Kumulatiewe } \\
\text { frekwensie }\end{array}$ & $\begin{array}{l}\text { Kumulatiewe } \\
\text { persentasie }\end{array}$ \\
\hline 1 & 13 & 16,25 & 13 & 16,25 \\
\hline 2 & 12 & 15,00 & 25 & 31,25 \\
\hline 3 & 6 & 7,50 & 31 & 38,75 \\
\hline 4 & 31 & 38,75 & 62 & 77,50 \\
\hline 5 & 18 & 22,50 & 80 & 100,00 \\
\hline
\end{tabular}

Die minderheid van die respondente $(31,25 \%)$ het aangetoon dat die situasie van verandering in die land hulle nie negatief maak nie. $61,25 \%$ van die respondente het aangetoon dat hulle gedeeltelik of volkome daarmee saamstem dat die situasie van verandering in die land hulle negatief maak. Die situasie van verandering beïnvloed dus hoorders se gesindhede. 
Respondente het soos volg gereageer op stelling 21: "My verhouding met God gee my moed vir die toekoms":

\begin{tabular}{|c|r|r|r|r|}
\hline Stelling & Frekwensie & Persentasie & $\begin{array}{l}\text { Kumulatiewe } \\
\text { frekwensie }\end{array}$ & $\begin{array}{l}\text { Kumulatiewe } \\
\text { persentasie }\end{array}$ \\
\hline 3 & 2 & 2,50 & 2 & 2,50 \\
\hline 4 & 11 & 13,75 & 13 & 16,25 \\
\hline 5 & 67 & 83,75 & 80 & 100,00 \\
\hline
\end{tabular}

Geen respondent het matig of sterk van die stelling verskil nie. Bykans al die respondente $(97,5 \%)$ het gedeeltelik of volkome met die stelling saamgestem. Alhoewel respondente onder stelling 20 aangetoon het dat die situasie van verandering in die land hulle negatief maak, het hulle onder stelling 21 aangetoon dat hulle verhouding met God hulle tog moed vir die toekoms gee.

Respondente het soos volg gereageer op stelling 22: "Preke moet 'n groter rol speel om lidmate te help om die regte (gelowige) toekomsverwagting te hê":

\begin{tabular}{|c|r|r|r|r|}
\hline Stelling & Frekwensie & Persentasie & $\begin{array}{l}\text { Kumulatiewe } \\
\text { frekwensie }\end{array}$ & $\begin{array}{l}\text { Kumulatiewe } \\
\text { persentasie }\end{array}$ \\
\hline 1 & 1 & 1,25 & 1 & 1,25 \\
\hline 2 & 3 & 3,75 & 4 & 5,00 \\
\hline 3 & 4 & 5,00 & 8 & 10,00 \\
\hline 4 & 10 & 12,50 & 18 & 22,50 \\
\hline 5 & 62 & 77,50 & 80 & 100,00 \\
\hline
\end{tabular}

Die meerderheid van die respondente $(90 \%)$ het aangetoon dat preke 'n groter rol moet speel om hoorders te help om die regte toekomsverwagting te hê. Slegs $6,25 \%$ van die respondente het aangetoon dat preke nie 'n rol moet speel in die vorming van die regte toekomsverwagting nie. Prediking moet te midde van oorgangstye en tye van verandering lidmate help om die regte toekomsverwagting te vorm. 


\section{Afleidings ten opsigte van gesindhede oor die toekoms}

- Ouer lidmate se gesindheid oor die toekoms is minder positief, terwyl jonger mense in die ontvanklike stadium van gesindheidsvorming meer positief oor die toekoms is.

- Respondente (hoorders) se gesindheid is positief teenoor hulle verhouding met God. Die verhouding met God gee te midde van onsekerheid oor die toekoms aan hulle 'n anker om aan vas te hou.

- Prediking moet lidmate help om die regte gesindheid oor die toekoms te hê.

\section{Samevattende stellings oor tendense}

Op grond van die homileties-empiriese navorsing oor prediking en gesindheidsverandering kan sekere tendense uitgesonder word. Uit die gesindheidskaal het dit geblyk dat hoorders oor duidelik onderskeibare gesindhede beskik wat veral die volgende sake betref:

- Soorte gesindhede sluit die volgende in:

- Gesindhede wat afhanklik is van kerklik-sosiale faktore weerspieël die mate waarin godsdienstige betrokkenheid afhanklik is van kontak met ander gelowiges.

- Gesindhede wat persoonlike voordeel in die oog het, wentel rondom die mate waarin die betekenis van iemand se godsdiens gesoek word in die persoonlike troos en steun wat dit bied.

- Intrinsiek-godsdienstige gesindhede het te make met die gerigtheid op die verhouding met God en die strewe om dit met daaglikse ervarings te verbind.

- Gesindhede oor spesifieke sake sluit die volgende in: gesindheid teenoor die Woord, gesindheid teenoor die gemeente, gesindheid teenoor die erediens en prediking en gesindheid oor die toekoms.

- Prediking het 'n onthullende aard. Die prediker se gesindheid teenoor die prediking en gemeente word weerspieël in die wyse waarop preke voorberei en gelewer word. Die gesindheid van die prediker oefen 'n invloed uit op die gesindheid van hoorders.

- Geleenthede ten opsigte van sinvolle preekgesprekke kan hoorders stimuleer in die behoefte wat hulle het om met medegelowiges oor die prediking te gesels.

- Predikers moet bedag wees op die wyse waarop hulle met die preek omgaan. Langdradige en moeilik verstaanbare preke bemoeilik vol- 
gens hoorders die luisterproses en bring mee dat hulle met inspanning hieraan deelneem.

- Hoorders wil graag praktiese hulp uit preke bekom. Die preek moet soos 'n lading plofstof wees wat hoorders tot nuwe insigte bring. 'n Goeie preek is vir hoorders 'n preek wat die teks verklaar en prakties toepas.

- Geloof in God stel hoorders in staat om met oortuiging te lewe en op te tree. Preke wat leiding aan hoorders gee ten opsigte van die praktyk van die lewe, help hoorders in die neem van moeilike besluite.

- Die gesindhede van hoorders word alreeds van kindsbeen af gevorm. Hoorders is bereid om hulle gesindheid en optrede te verander indien God se Woord dit van hulle eis. Binne die Suid-Afrikaanse konteks dui die respons 'n belangrike tendens aan ten opsigte van die gesindheidsdimensie in aspekte soos volkereverhoudings, die ingesteldheid ten opsigte van vigs, misdaad en armoede.

- Alhoewel die meerderheid hoorders erken het dat die gesindheid van ander lidmate hulle beïnvloed, blyk dit dat 'n beduidende aantal hoorders nie hiermee saamstem nie. Hoorders wil nie graag erken dat ander lidmate en persone hulle beïnvloed nie.

- Hoorders wil graag met hulle predikant in gesprek tree oor preke wat hulle ongemaklik laat voel vanweë hulle verkeerde gewoontes en gesindhede. Predikers moet by hoorders die vrymoedigheid stimuleer om oor preke te gesels wat hulle ongemaklik laat voel vanweë verkeerde gesindhede.

- Die gesindheid oor die toekoms vorm 'n integrale deel van 'n gelowige se lewe. Hoorders openbaar egter uiteenlopende sienings oor die toekoms en situasie van verandering in die land. Die situasie van verandering in die land beïnvloed hoorders se gesindheid oor die toekoms.

- Hoorders ervaar 'n pessimisme oor die toekoms, maar erken tog dat hulle verhouding met God as anker dien in hulle toekomsverwagting.

- Prediking moet volgens hoorders 'n belangrike rol speel in die kweek van 'n gelowige toekomsverwagting. In die prediking moet die hoorders se uitkyk op die toekoms nog sterker gebind word aan hulle verhouding tot God om sodoende 'n positiewe uitkyk op die toekoms te help vorm.

- Prediking vorm saam met die ander gestaltes van gemeentelike bediening 'n belangrike middel om gesindhede te verander, te handhaaf of te vorm . 


\section{Bibliografie}

ADAY, A.D. \& ANDREW, M.G. 1996. Getting it right. The managers guide to business communication. Kaapstad : Creda.

BURGER, C.W. 1994. Die agogiese moment in die prediking in 'n situasie van verandering. Praktiese Teologie in Suid-Afrika, 9(1):83-92.

CILLIERS, J. 1996. Die uitwissing van God op die kansel. Ontstellende bevindinge oor Suid-Afrikaanse prediking. Kaapstad : Lux Verbi.

CILLIERS, S.P. 1983. Maatskaplike navorsing. Stellenbosch : Kosmos.

DANE, F.C. 1990. Research methods. California : Belmont.

DINGEMANS, G.D.J. 1991. Als hoorder onder de hoorders. Kampen : Kok.

FIRET, J. 1978. Het agogisch moment in het pastoraal optreden. Kampen : Kok.

HEYNS, J.A. 1982. Teologiese etiek. Kaapstad : Nasionale Boekdrukkery.

KIM, H.K. \& VENTER, C.J.H. 1999. Equiping the congregation by means of preaching: Paul's sermon at Miletus (Acts 20:17-38) - perspectives for the South African context. In die Skriflig, 33(4):509-524, Maart.

KRUGER, F.P. 2002. Prediking en gesindheidsverandering. 'n Prakties-Teologiese studie in die lig van Hebreërs. Potchefstroom : PU vir CHO. (Th-D.-proefskrif.)

KRUGER, F.P. \& VENTER, C.J.H. 2002. Prediking en die gesindheid van hoorders. Basisteoretiese perspektiewe vanuit Hebreërs. In die Skriflig, 36(4):573-592, Desember.

NEL, M. 1994. Gemeentebou. Halfwayhouse : Orion.

NEL, M. 1999. Images of Jesus among the South African youth. Praktiese Teologie in Suid-Afrika, 14(2):62-86.

NEL, M. 2000. Persoonlike prediking. Praktiese Teologie in Suid-Afrika, 15(2):112135.

PIETERSE, H.J.C. 1988. Gemeente en prediking. Halfway House : NG Kerkboekhandel.

PRINS, J.M.G. 2000. Die godsdienstige houdings van kerklike betrokke tieners. Praktiese Teologie in Suid-Afrika, 15 (1):82-100.

RICHARDS, L.O. 1988. Children's ministry. Grand Rapids : Zondervan.

SCHOONEES, P.C., hoofred. 1972. Woordeboek van die Afrikaanse Taal. Pretoria : Staatsdrukker.

SMIT, A. 1995. Nuut gedink oor leierskap in gemeentes. (In Burger, C., Hendriks, J., Van der Merwe, M. \& Smit, A., red. Gemeente en bediening. Nuut gedink oor leierskap in gemeentes. Die begeleiding van 'n Christelike gemeenskap. Kaapstad : Lux Verbi. p.16-36.)

SMIT, G.J. 1985. Navorsingsmetodes in die Gedragswetenskappe. Pretoria : Opvoedkundige Uitgewers.

SMIT, P.J. \& DE J. CRONJE, G.J. 1999. Management principles. Kenwyn : Juta.

VOS, C.J.A. 1995. Die blye tyding. Pretoria : RGN.

VOS, C.J.A. 1999. The composition of a sermon. PraktieseTeologie in Suid-Afrika, 14(2):120-128.

WAT

kyk Schoonees, P.C. et al.

\section{Kernbegripe:}

gesindheid

gesindheidsverandering

prediking 
Key concepts:

attitude

attitude change

preaching 